\title{
DIAMONDIFEROUS ARCHAEAN LAMPROPHYRES WITH KOMATIITIC AFFINITIES FROM THE WAWA AREA, ONTARIO, CANADA
}

\author{
Kaminsky FV, Sablukov* SM and Sablukova LI
}

A number of diamond-bearing eruptive bodies with peculiar compositions occur in the Wawa area, northwestern Ontario, Canada. These rocks comprise dyke-like bodies, quite commonly with unclear and hardly discernible contacts with their host rocks. The $\mathrm{Rb}-\mathrm{Sr}$ age of the dykes varies from $1550 \mathrm{Ma}$ to $2800 \mathrm{Ma}$. The rocks have a breccia-type clastic lava texture due to varying proportions of rock xenoliths in a metamorphosed, finegrained groundmass of lava appearance. Oval and elongate xenolithic segregations are mostly inclusions of various metamorphic rocks, microquarzite, diabase and microdolerite. The only exception is the Sandor dyke, where many xenoliths are transformed into a coarse-to-megacrystalline, radial actinolite aggregates. The groundmass of the rocks has a porphyroblastic texture composed of biotite, actinolite and, occasionally, feldspar and carbonate. Biotite has a high $\mathrm{Al}_{2} \mathrm{O}_{3}$ content and moderate $\mathrm{TiO}_{2}$ and $\mathrm{FeO}$ contents, being very similar in composition to biotite from the Akluilak diamondiferous minette (Parker Lake area, Nunavut, Canada). Based upon modal mineralogy (amphibole + biotite \pm plagioclase), the Wawa rocks are similar to calc-alkaline lamprophyres of spessartite or kersantite type, however, they differ in rock texture and in mineral chemistry. The norm of the rocks includes orthoclase, plagioclase, diopside, olivine and (except the Sandor dyke) hypersthene, which is close to trachybasaltic. In the TAS classification diagram, these rocks correspond to basanite (Sandor dyke), picro-basalt and basalt (other dykes). The ratio of $\mathrm{Al}-(\mathrm{Fe}+\mathrm{Ti})-\mathrm{Mg}$ shows that the rocks are similar to komatiitic basalt. In some dykes, the REE distribution is similar to komatiites. The concentrations of incompatible elements in the Wawa rocks are generally very low. Based upon the ratios of Th-Hf-Ta, all of these rocks are most similar to calc-alkaline, volcanic arc basalts. The concentrations of compatible elements in the Wawa rocks (Co up to $100 \mathrm{ppm}$, Ni up to $1500 \mathrm{ppm}$, $\mathrm{Cr}$ up to 3400 $\mathrm{ppm}$ ) are typical of ultramafic rocks and, in particular, of kimberlites. Further evidence in support of a deep-seated origin for the Wawa rocks is the presence of inclusions of megacrystalline actinolite, which are similar in Ni, Co and $\mathrm{Cr}$ content to ultramafic mantle nodules from kimberlite pipes. In the Crystal dyke pyroclastic breccia, we have also identified a segregation of $\mathrm{Cr}$-phlogopite $\left(1.56 \% \mathrm{Cr}_{2} \mathrm{O}_{3}\right)$ with a characteristic, radiate-fibrous structure, which may be a pyrope inclusion completely replaced by kelyphitic material. In dyke 51263 we found an inclusion with a zoned structure, the core of which consists of chromite $\left(50.61 \% \mathrm{Cr}_{2} \mathrm{O}_{3}\right)$. Diamonds in the Wawa lamprophyres are represented both by rounded crystals of the first generation and flat-faced microdiamonds of the second generation. 